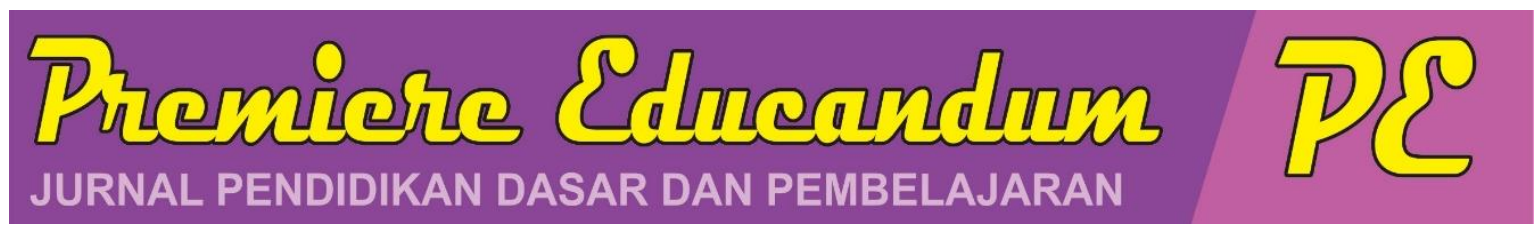

Premiere Educandum: Jurnal Pendidikan Dasar dan Pembelajaran

Volume 8(1) 1 - 14 Juni 2018

Copyright (C2018 Universitas PGRI Madiun

ISSN: 2088-5350 (Print) / ISSN: 2528-5173 (Online)

Available at: http://e-journal.unipma.ac.id/index.php/PE

Doi: $10.25273 /$ pe.v8i1.1332

\title{
Pengembangan media flashcard tematik berbasis permainan tradisional untuk kelas IV sub tema lingkungan tempat tinggalku
}

\author{
Rima Wulan Safitri ${ }^{1)}$, Cicilia Novi Primiani' ${ }^{2)}$ \& Hartini Hartini $^{3)}$ \\ 1,2,3FKIP, Universitas PGRI Madiun \\ 1email: rimasahari005@gmail.com \\ 2email: primiani@unipma.ac.id \\ 3 email: hartini@ unipma.ac.id
}

\begin{abstract}
Problems integrative thematic learning in elementary schools are academic subjects still taught separately, the absence of media intermediaries supported the learning process because it is only fixated on the handbook and not developed play while learning. This research development aims to generate a flashcard thematic instructional media based traditional games in integrative thematic learning of class IV subtheme of Lingkungan Tempat Tinggalku. Research method using 4D model (define, design, develop and disseminate). Media tested on 20 students of grade IV SDN Gunungsari Madiun. Data of exploration stage collected through observation and interview, while in development stage collected through questionnaires. The result showed that: (1) validation result from two validator of media and material aspect indicate that media is very feasible to be used in learning, (2) result of small and wide scale student response indicate that media is very feasible with $100 \%$ percentage (3) The result of learning before and after being treated showed significant difference, the test of learning hypothesis 2 obtained t-count $=8,376>$ t-table $=2,093$, in learning 5 obtained $=7,264>=2,093$. The results showed that the flashcard thematic instructional media based traditional games for grade 4 students subtheme lingkungan tempat tinggalku is very feasible.
\end{abstract}

Keywords: instructional media, integrative thematic, thematic flashcard, games.

\section{Abstrak}

Permasalahan dalam pembelajaran tematik integratif di sekolah dasar yaitu mata pelajaran masih diajarkan secara terpisah, tidak adanya media perantara yang mendukung proses pembelajaran karena hanya terpaku pada buku pegangan dan belum dikembangkan aktivitas bermain sambil belajar. Penelitian pengembangan ini bertujuan untuk menghasilkan media pembelajaran flashcard tematik berbasis permainan tradisional yang layak untuk pembelajaran tematik integratif kelas IV sub tema Lingkungan Tempat Tinggalku. Metode penelitian menggunakan model 4D (define, design, develop and disseminate). Media diujikan pada 20 siswa kelas IV SDN Gunungsari Madiun. Instrumen pengumpulan data yang digunakan dalam tahap eksplorasi yaitu observasi dan wawancara, sedangkan dalam tahap pengembangan berupa angket. Hasil penelitian menunjukkan bahwa: (1) hasil validasi dari dua validator ahli aspek media dan materi menunjukkan bahwa media sangat layak digunakan dalam pembelajaran, (2) hasil respon siswa skala kecil dan luas menunjukkan bahwa media sangat layak dengan persentase $100 \%$ dan (3) hasil belajar sebelum dan setelah diberi perlakuan menunjukkan perbedaan yang signifikan, uji hipotesis pembelajaran 2 diperoleh $t_{\text {hitung }}=8,376>$ $t_{\text {tabel }}=2,093$, dalam pembelajaran 5 diperoleh $t_{\text {hitung }}=7,264>t_{\text {tabel }}=2,093$. Hasil penelitian menunjukkan bahwa media pembelajaran flashcard tematik berbasis permainan tradisional sangat layak digunakan untuk kelas IV sub tema Lingkungan Tempat Tinggalku.

Kata kunci: media pembelajaran, tematik integratif, flashcard tematik, permainan.

Histori artikel : disubmit pada 22 Juni 2017; direvisi pada 7 Juli 2017; diterima pada 21 Desember 2017 


\section{A. PENDAHULUAN}

- Pembelajaran tematik integratif merupakan pembelajaran yang didasarkan pada tema sebagai pengikat untuk mempersatukan bahasan antar materi sehingga tidak ada pemisahan yang jelas antar mata pelajaran. Menurut Prastowo (dalam Indriani, 2015) karakteristik pembelajaran tematik integratif antara lain; (1) berpusat pada siswa; (2) pemisahan mata pelajaran tidak terlalu jelas; (3) mengembangkan keterampilan siswa; (4) menggunakan prinsip bermain sambil belajar; (5) mengembangkan komunikasi siswa; (7) menyajikan pembelajaran sesuai tema; dan (8) menyajikan pembelajaran dengan memadukan berbagai mata pelajaran. Penggunaan tema dalam pembelajaran tematik integratif merupakan upaya untuk mendorong siswa ke dalam kegiatan yang menyenangkan, aktif dan bermakna.

Menurut Chirnawati, dkk (2016) kendala yang dihadapi guru dalam pembelajaran tema yaitu guru cenderung mengalami kesulitan dalam mendesain pembelajaran karena membutuhkan kreativitas untuk menyajikan kajian baik intra dan inter mata pelajaran dalam satu tema yang terjalin tanpa ada batas yang jelas. Kendala lain yang sering terjadi dan tidak sesuai dengan karakteristik pembelajaran tematik integratif menurut Yuliyanti (2016) yaitu penggunaan aktivitas bermain sambil belajar dalam pembelajaran masih kurang.

Pengembangan

pembelajaran menggunakan media pembelajaran yang didesain secara tematik diperlukan untuk mengatasi kesulitan guru dalam menyajikan beberapa mata pelajaran dalam satu tema. Melalui media yang telah disiapkan diharapkan guru mampu membuat alur kegiatan secara terpadu dalam kegiatan pembelajaran (Chirnawati, dkk, 2016). Media pembelajaran tematik dapat diartikan sebagai perantara berisi pesan atau materi dari beberapa mata pelajaran yang akan disampaikan oleh guru serta dapat diterima dan dipelajari oleh siswa. Penggunaan media tematik yang dipadukan dengan aktivitas bermain mampu mengembangkan kemampuan dan potensi siswa dalam berpikir, berkreatif dan bersosialisasi.

Buku pegangan guru dan siswa merupakan sumber belajar sekaligus media pembelajaran yang selama ini disediakan pemerintah dalam kegiatan pembelajaran tematik integratif. Buku pegangan berisi media dari berbagai mata pelajaran yang berkaitan dengan tema, tetapi penggunaanya belum mendukung proses pembelajaran. Guru cenderung mengalami kesulitan dalam mengintegrasikan isi buku, sehingga mengakibatkan kurangnya aktivitas dan pemahaman siswa mengenai isi materi.

Aktivitas bermain yang sesuai jika dikembangkan dalam pembelajaran tematik integratif adalah permainan tradisional. Menurut Hidayat (2013) permainan tradisional dapat menstimulasi berbagai perkembangan anak seperti aspek motorik, kognitif, emosi, sosial dan spiritual anak. Materi dan fungsi permainan tradisional merupakan media yang tepat untuk diintegrasikan ke dalam kegiatan pembelajaran. Melalui permainan tradisional, siswa dapat belajar dengan cara yang menyenangkan.

Permasalahan mengenai kendala penerapan pembelajaran tematik integratif juga terjadi di Sekolah Dasar Negeri (SDN) Gunungsari Madiun. Ketersedian sumber belajar di SDN 
Gunungsari Madiun seperti media pembelajaran terbatas. Media sebelumnya yang digunakan di SDN Gunungsari tercantum dalam buku pegangan siswa berupa media gambar namun penggunaannya belum maksimal dan belum terintegrasi dengan permainan.

Kelemahan dari media yang terdapat dalam buku pegangan yaitu siswa cenderung mengalami kesulitan memahami isi materi tanpa ada media perantara yang mendukung. Media yang berada pada buku siswa cenderung untuk pembelajaran mandiri, sehingga siswa kurang tertarik dan interaksi keaktifan antar siswa kurang terwujud. Menurut guru, media pembelajaran tematik yang dipakai hanya terfokus pada buku pegangan. Pemilihan media yang terdapat dalam buku pegangan dinilai lebih praktis baik dari segi persiapan maupun pelaksanaannya.

Berdasarkan permasalahan yang terjadi dalam pembelajaran tematik integratif di SDN Gunungsari maka diperlukan adanya pengembangan variasi media pembelajaran untuk kelas IV dengan menggunakan media flashcard tematik berbasis permainan tradisional yang dapat digunakan sebagai perantara untuk menyampaikan materi secara tematik sehingga tidak ada pemisahan yang jelas antar mata pelajaran sekaligus mendukung pembelajaran bermakna bagi siswa.

Media flashcard tematik merupakan media pengembangan dari flashcard yang dipadukan dengan permainan tradisional. Flashcard berisi gambar, teks, atau tanda simbol dan uraian yang mengacu hanya pada satu mata pelajaran dikembangkan menjadi media tematik yaitu dipadukan dengan indikator dari minimal dua mata pelajaran dalam pembelajaran 2 dan 5 sub tema Lingkungan Tempat Tinggalku.

Media flashcard tematik digunakan sebagai alat permainan edukatif berbentuk kartu berisi materi dan pertanyaan dari berbagai mata pelajaran yang disatukan dalam satu sub tema yaitu Lingkungan Tempat Tinggalku. Penggunaan media flashcard tematik dipadukan dengan permainan tradisional keplakan dan tekpo yang awalnya dimainkan dengan menggunakan kartu umbul.

Berdasarkan penelitian yang dilakukan oleh Maghfiroh (2013), penggunaan media flashcard pada tema Pekerjaan mampu meningkatkan aktivitas guru dan siswa dalam pembelajaran. Hasil penelitian Susiani \& Supriyono (2014) diperoleh kesimpulan bahwa penggunaan media kartu bergambar pada tema Diriku Sendiri dapat mendorong siswa menjadi lebih aktif dalam bekerja kelompok, mendengarkan penjelasan dan menjawab pertanyaan dari guru.

Media yang dipadukan dengan permainan tradisional akan lebih menarik minat siswa dalam belajar. Berdasarkan hasil penelitian Anggraini \& Untari (2014), penggunaan permainan tradisional mampu meningkatkan hasil belajar tema Diriku dan mampu memunculkan nilai-nilai karakter pada siswa. Penelitian serupa mengenai permainan tradisional juga dilakukan oleh Syamsiana \& Lutfi (2014) yang dapat disimpulkan bahwa penyampaian materi pembelajaran yang dipadukan dengan permainan tradisional mempunyai daya tarik tersendiri bagi siswa, sehingga siswa lebih mudah menyerap materi dan mampu menciptakan pembelajaran yang menyenangkan bagi siswa. 


\section{B. METODE PENELITIAN}

Model pengembangan yang digunakan yaitu model pengembangan prosedural yang mengutamakan langkahlangkah untuk menghasilkan produk tertentu. Langkah-langkah penelitian dan pengembangan yang digunakan yaitu dikemukakan oleh Thiagarajan, Semmel $\&$ Semmel (dalam Arifin, 2011) prosedur pengembangan memiliki empat tahap (4D) yaitu (1) define (pendefinisian), (2) design (perancangan), (3) develop (pengembangan),

disseminate (penyebarluasan).

Tahap pendefinisian meliputi analisis ujung depan, siswa dan konsep pembelajaran. Analisis ujung depan untuk mengetahui kurikulum dan media yang digunakan di SDN Gunungsari serta mengetahui permasalahan yang dihadapi guru dan siswa dalam pembelajaran tematik integratif serta menentukkan solusinya.

Analisis siswa bertujuan untuk mengetahui karakteristik siswa dan masalah yang dihadapi siswa. Analisis konsep digunakan untuk mengindentifikasi, merinci dan menyusun materi yang terdapat dalam sub tema Lingkungan Tempat Tinggalku pembelajaran 2 dan 5. Langkah kedua yaitu mengidentifikasi tujuan pembelajaran.

Tahap pertama perancangan yaitu penyusunan materi dan soal berdasarkan indikator setiap mata pelajaran. Tahap kedua yaitu merancang bentuk media yang akan dikembangkan berdasarkan kesesuaian dengan materi pembelajaran, tujuan pembelajaran dan karakteristik siswa.

Tahap pengembangan meliputi validasi ahli dan uji coba produk. Tahap validasi meliputi validasi ahli materi dan validasi ahli media sesuai dengan kriteria kualitas kelayakan. Media pembelajaran flashcard tematik yang sudah dirancang akan diuji validasi melalui angket. Tujuan tahap validasi yaitu untuk mendapat saran-saran yang diberikan validator guna memperbaiki produk kemudian dilakukan revisi (perbaikan). Hasil validasi digunakan untuk menentukan bahwa media memenuhi kriteria layak untuk diujicobakan.

Produk hasil validasi ahli diujikan pada kelas kecil yaitu siswa kelas IV SDN Gunungsari Madiun dengan jumlah 10 siswa. Tahap uji coba kelas kecil digunakan untuk mengambil data respon siswa setelah menggunakan media pembelajaran flashcard tematik berbasis permainan tradisional, selanjutnya hasil uji coba dianalisis kelayakan sehingga dapat diujikan pada skala luas untuk mengetahui kelayakan dan keefektivitas media. Tahap akhir disseminate yaitu publikasi di jurnal prodi PGSD Universitas PGRI Madiun.

Jenis data yang diperoleh dalam pengembangan ini adalah data kualitatif dan kuantitatif. Data kualitatif diperoleh dari hasil obervasi, wawancara, saran validasi media dan validasi instumen tes. Data kuantitatif diperoleh dari angket hasil validasi berupa angket yang diberikan kepada ahli aspek materi maupun media, respon siswa dan hasil keefektivitas media.

Penilaian dari validator dan angket respon siswa menggunakan skala Likert dinyatakan dalam bentuk pernyataan. Hasil akhir validasi aspek media dan materi dihitung dengan rumus persentase sebagai berikut:

Nilai akhir $=\frac{\text { jumlah skor gabungan }}{\text { jumlah skor maksimal }} \times 100 \%$ 
Persentase yang diperoleh melalui perhitungan kemudian diinterpretasikan berdasarkan kriteria kelayakan tabel berikut ini:

Tabel 1. Kriteria Interprestasi Media

\begin{tabular}{ll}
\hline Penilaian & Kriteria Intepretasi \\
\hline $0,01-1,00$ & Tidak Baik \\
\hline $1,01-2,00$ & Kurang Baik \\
\hline $2,01-3,00$ & Cukup Baik \\
\hline $3,01-4,00$ & Baik \\
\hline $4,01-5,00$ & Sangat Baik \\
\hline
\end{tabular}

Analisis angket respon siswa digunakan untuk mengetahui respon siswa setelah menggunakan media flashcard tematik berbasis permainan tradisional dalam pembelajaran. Analisis data hasil angket respon siswa dianalisis dengan rumus sebagai berikut:

$$
N . A=\frac{\text { jumlah skor rata }- \text { rata }}{\text { jumlah siswa }}
$$

Tabel 2. Kriteria Interprestasi Angket Respon

\begin{tabular}{cc}
\hline Penilaian & Kriteria Intepretasi \\
\hline $0 \%-20 \%$ & Sangat Tidak Layak \\
\hline $21 \%-40 \%$ & Tidak Layak \\
\hline $41 \%-60 \%$ & Cukup Layak \\
\hline $61 \%-80 \%$ & Layak \\
\hline $81 \%-100 \%$ & Sangat Layak \\
\hline & Siswa
\end{tabular}

Analisis uji coba instrumen tes menggunakan validitas isi yang dinilai oleh guru. Validitas isi dilakukan dengan membandingkan antara isi instrumen dengan kompetensi yang dikembangkan dan materi pelajaran yang dipelajari.

Hasil belajar siswa dalam pembelajaran 2 dan 5 ditentukan dengan menggunakan uji t berpasangan. Syarat dilakukannya uji $\mathrm{t}$ berpasangan yaitu menggunakan uji normalitas. Uji normalitas digunakan untuk menentukan bahwa sampel setelah diberi perlakuan berasal dari polulasi berdistribusi normal.
Analisis hasil belajar siswa digunakan untuk mengetahui perbedaan hasil belajar setelah menggunakan media flashcard tematik berbasis permainan tradisional dalam pembelajaran. Hasil belajar siswa sebelum diberi perlakuan berasal dari data guru berupa nilai kognitif pembelajaran 2 dan 5. Analisis data perbedaan hasil belajar siswa menggunakan rumus sebagai berikut:

$$
\begin{gathered}
s=\sum d^{2}-\frac{\sum(d)^{2}}{n} \\
t=\frac{\overline{\bar{D}}}{\sqrt{\frac{s}{n(n-1)}}}
\end{gathered}
$$

Hipotesis penggunaan media pembelajaran flashcard tematik berbasis permainan tradisional adalah sebagai berikut:

$\mathrm{H}_{\mathrm{o}}$ : Tidak terdapat perbedaan hasil belajar kognitif siswa setelah menggunakan media perbelajaran flashcard tematik berbasis permainan.

$\mathrm{H}_{\mathrm{a}}$ : Terdapat perbedaan hasil belajar kognitif siswa setelah menggunakan media perbelajaran flashcard tematik berbasis permainan.

\section{HASIL DAN PEMBAHASAN Hasil Penelitian}

Pengembangan media pembelajaran flashcard tematik berbasis permainan tradisional untuk kelas IV sub tema Lingkungan Tempat Tinggalku di SDN Gunungsari Madiun dilakukan sesuai tahapan model pengembangan 4D. Hasil pengembangan flashcard tematik adalah meliputi beberapa tahap sebagai berikut:

\section{a. Tahap Pendefinisian}

Tahap pendefinisian terdiri dari beberapa analisis sebagai berikut:

1. Analisis Ujung Depan dan Siswa 
Data yang diperoleh dari analisis ujung depan yaitu bahwa kurikulum yang digunakan di kelas IV SDN Gunungsari adalah kurikulum 2013 dan siswa kelas IV SDN Gunungsari merupakan individu yang aktif serta senang bermain. Permasalahan yang terjadi dalam pembelajaran tematik integratif yaitu adanya kesulitan yang dialami guru dalam mengintegrasikan beberapa mata pelajaran dalam satu tema maupun sub tema, siswa cenderung mengalami kesulitan dalam memahami isi buku pegangan karena keterbatasan sumber dan media pembelajaran serta belum dikembangkannya aktivitas bermain sambil belajar.

2. Analisis Konsep

Materi yang digunakan yaitu terdapat dalam tema 8 Tempat Tinggalku sub tema Lingkungan Tempat Tinggalku pembelajaran 2 dan 5. Adapun materi dalam pembelajaran 2 sub tema Lingkungan Tempat Tinggalku yaitu: kondisi alam suatu tempat; kenampakan alam daratan dan dampaknya; perbedaan daratan pantai, rendah dan tinggi; kondisi alam Kepulauan Seribu dan teks Kepulauan Seribu. Tujuan dari pembelajaran kedua adalah sebagai berikut: (1) Setelah membaca teks, siswa mampu menuliskan informasi berdasarkan teks, (2) Setelah membaca teks, siswa mampu menyimpulkan hubungan keadaan alam dengan kehidupan masyarakat Kepulauan Seribu dengan benar, (3) Setelah membaca teks, siswa mampu menceritakan kembali dengan runtut, (4) Setelah mengamati peta, siswa mampu membedakan dataran pantai, rendah, dan tinggi dengan benar dan (5) Setelah mengamati peta, siswa mampu menjelaskan dampak kondisi alam bagi masyarakat dengan benar.
Materi dalam pembelajaran 5 sub tema Lingkungan Tempat Tinggalku yaitu: rute perjalanan, posisi suatu benda, kewajiban masyarakat, pajak dan sarana umum. Tujuan dari pembelajaran kelima adalah sebagai berikut: (1) Setelah mengamati denah, siswa mampu membuat pertanyaan berdasarkan teks yang diberikan dengan benar, (2) Setelah mengamati denah, siswa mampu menyelesaikan masalah yang terkait dengan denah dengan benar, (3) Setelah mengamati gambar, siswa mampu menjelaskan sarana umum dan manfaatnya dengan benar, (4) Setelah berdiskusi, siswa mampu menjelaskan manfaat pajak dengan benar, (5) Setelah mengamati gambar siswa mampu menjelaskan pentingnya orang membayar pajak dengan benar dan (6) Setelah mengamati gambar, siswa mampu menjelaskan kewajiban orang untuk merawat sarana umum dengan benar.

\section{b. Tahap Perancangan}

Tahap kedua adalah tahap perancangan. Langkah pertama yang dilakukan dalam tahap ini adalah penyusunan materi dan soal. Materi dalam flashcard tematik satu seri pertama yaitu mata pelajaran IPA dipadukan dengan IPS mengenai kenampakan alam daratan dan dampaknya; perbedaan daratan pantai, rendah dan tinggi serta kondisi alam suatu tempat. Materi dalam flashcard tematik materi dua seri pertama yaitu mata pelajaran Bahasa Indonesia dipadukan dengan IPS mengenai Teks Kepulauan Seribu dan Kondisi alam Kepulauan Seribu.

Soal-soal yang terdapat pada flashcard challenge seri pertama berdasarkan indikator dari tiga mata pelajaran yaitu IPS, IPA dan Bahasa Indonesia. Indikator dari mata pelajaran 
IPS yaitu mampu menjelaskan kondisi alam Kepulauan Seribu, menjelaskan kenampakan alam daratan dan dampaknya bagi masyarakat dan membedakan dataran pantai, rendah, dan tinggi. Indikator dari mata pelajaran IPA yaitu meyebutkan kondisi alam suatu tempat dan menjelaskan pemanfaatan SDA bagi masyarakat. Indikator dari mata pelajaran Bahasa Indonesia yaitu menuliskan kondisi alam pulau Kepulauan Seribu dan menceritakan kembali teks tentang Kepulauan Seribu.

Materi yang terdapat pada flashcard tematik materi seri kedua juga dibedakan menjadi dua. Materi dalam flashcard tematik satu seri kedua yaitu mata pelajaran Matematika dipadukan dengan IPS mengenai rute perjalanan, posisi suatu benda dan sarana umum. Materi dalam flashcard tematik dua seri kedua yaitu mata pelajaran IPS dipadukan dengan PPKn mengenai pajak dan kewajiban sebagai warga negara.

Soal-soal yang terdapat pada flashcard challenge seri kedua berdasarkan indikator dari tiga mata pelajaran yaitu IPS, Matematika dan PPKn. Indikator dari mata pelajaran PPKn yaitu menyebutkan kewajiban sebagai masyarakat dan menjelaskan cara menjaga sarana umum. Indikator dari mata pelajaran IPS yaitu menjelaskan manfaat pajak dan menjelaskan pentingnya orang membayar pajak. Indikator dari mata pelajaran Matematika yaitu membuat pertanyaan mengenai posisi suatu benda dan menyelesaikan masalah yang terkait dengan rute perjalanan.

Format media flashcard tematik yang digunakan yaitu format cetak. Media pembelajaran flashcard tematik dibedakan menjadi dua macam yaitu flashcard tematik materi dan flashcard challenge dan dilengkapi dengan buku petunjuk penggunaan. Flashcard tematik materi terdiri dari dua bagian yaitu bagian depan dan belakang, tampilan kartu bagian depan berisi teks tulisan pembelajaran 2 atau 5 dengan font dan warna berbeda di setiap pembelajaran dan background gambar tema Tempat Tinggalku. Tampilan kartu bagian belakang berisi materi berupa gambar maupun teks dari indikator minimal dua mata pelajaran di setiap pembelajaran. Ukuran flashcard tematik materi yaitu $15 \times 9 \mathrm{~cm}$ untuk guru dan siswa.

Flashcard challenge juga terdiri dari dua bagian. Tampilan kartu bagian depan berisi gambar tema Lingkungan Tempat Tinggalku, tulisan flashcard challenge, gambar tangan, tulisan toss dan tekpo. Tampilan kartu bagian belakangan berisi teks "Kamu Bisa", angka, huruf dan pertanyaan tantangan dengan jumlah beragam yaitu satu hingga tiga pertanyaan. Setiap kelompok memiliki flashcard challenge yang sama tetapi dengan angka yang berbeda yaitu antara 77 sampai 100.

Desain awal buku petunjuk penggunaan disusun untuk guru yang berisi kompetensi inti, kompetensi dasar, indikator dari dari setiap pembelajaran, tujuan pembelajaran, pengenalan flashcard tematik, langkah penggunaan flashcard tematik dan kunci jawaban. Ukuran dari buku petunjuk pengunaan adalah 20x25 cm dengan background berwarna kuning dan dilengkapi gambargambar flashcard tematik. Desain sampul bagian depan berisi judul buku, sub tema Lingkungan Tempat Tinggalku, pembelajaran 2 dan 5, untuk guru SD/MI kelas IV, sedangkan bagian belakang berisi logo universitas, flashcard tematik 
materi dan challenge serta nama penulis. Isi buku dicetak pada kertas A4, sedangkan sampul buku pada kertas ad paper glory 100 laminating.

\section{c. Tahap Pengembangan}

1. Validasi Ahli

Validator terdiri dari dua ahli yaitu guru yang mengampu pembelajaran tematik integratif di sekolah dasar dan dosen yang mengampu mata kulaih inovasi penddikan dan pembelajaran terpadu. Masing-masing validator sebagai validator ahli materi dan media.

Berdasarkan analisis data hasil pengujian produk media pembelajaran flashcard tematik berbasis permainan tradisional pembelajaran 2 dan 5 aspek materi dikategorikan bahwa media sangat layak sesuai dengan aspek-aspek penilaian kualitas isi dan instruksional. Penilaian kualitas isi menunjukkan bahwa media yang dikembangkan sesuai dengan materi yang terdapat dalam buku tema 8 Tempat Tinggalku, soal sesuai dengan indikator-indikator dalam pembelajaran dan isi atau penggunaan sesuai dengan tujuan pembelajaran serta aspek kebahasaan jelas dan mudah dipahami. Penilaian kualitas instruksional meliputi bahwa penggunaan flashcard tematik berbasis permainan tradisional harus dapat memberikan dampak bagi siswa maupun guru.

Berdasarkan pada hasil pengujian media pembelajaran flashcard berbasis permainan tradisional aspek media, hasil persentase nilai total dari empat komponen diperoleh hasil 93,33\% untuk komponen pertimbangan produksi diperoleh skor 9, komponen peserta didik, isi dan guru memperoleh skor maksimal 10. Hasil pengujian aspek media dikategorikan sangat layak dan dikatakan memadai untuk bisa dilakukan uji kelayakan dalam proses pembelajaran.

Validator dua memberikan saran agar ukuran flashcard tematik materi untuk guru dibuat lebih besar dari ukuran flashcard tematik materi untuk siswa. Flashcard tematik materi untuk guru awalnya berukuran 9x15 cm diubah dengan ukuran 20,5x15,5 cm. Hasil perbaikan produk diujicobakan pada skala kecil dengan jumlah 10 siswa di SDN Gunungsari Madiun.

\section{Hasil Uji Pengembangan Skala Kecil}

Pengisian angket respon siswa pada uji kelas kecil diujikan pada 10 siswa kelas IV SDN Gunungsari yang dipilih secara acak. Pembelajaran dalam skala kecil hanya digunakan untuk menilai media yang dikembangkan tidak untuk dinilai hasil pembelajaran. Hasil angket respon siswa pada uji kelas kecil menunjukkan bahwa respon dari 10 siswa kelas IV SDN Gunungsari adalah sangat layak dengan persentase $100 \%$. Saran dan komentar rata-rata siswa yaitu menunjukkan bahwa proses pembelajaran menjadi menyenangkan. Hasil respon siswa pada uji kelas kecil menunjukkan bahwa media flashcard tematik berbasis permainan tradisonal dapat diujikan pada skala luas.

\section{Hasil Uji Pengembangan Skala Luas}

Pengisian angket uji skala luas diujikan pada semua siswa kelas IV SDN Gunungsari dengan jumlah 20 siswa. Hasil angket respon siswa uji skala luas menunjukkan bahwa respon dari 20 siswa adalah sangat layak dengan persentase $100 \%$. Hasil respon siswa pada uji kelas luas menunjukkan bahwa media yang dikembangkan sesuai dengan komponen ketertarikan yaitu dapat menimbulkan 
ketertarikan siswa dalam penggunaan dan proses pembelajaran serta dapat meningkatkan aktivitas siswa, komponen isi yaitu bahasa dalam media pembelajaran juga mudah dipahami dan jelas serta komponen penggunaan yaitu adanya kemudahan dalam menggunakan media maupun memahami materi.

\section{Hasil Uji Keefektivitas Media}

\section{(a) Hasil Validasi Instrumen Tes}

Hasil uji instrumen tes menunjukkan bahwa soal-soal dapat diberikan kepada siswa sebagai evaluasi dalam kegiatan pembelajaran 2 maupun 5 karena instumen telah sesuai dengan materi pelajaran dan indikator yang telah ditentukan.

\section{(b) Hasil Uji Prasyarat}

Hasil uji normalitas nilai dari 20 siswa setelah diberi perlakuan dengan taraf signifikansi 5\% yaitu diperoleh DK $=0,190$, dan $\mathrm{L}_{\mathrm{obs}}=0,1621$ pada pembelajaran 2 serta $\mathrm{DK}=0,190$ dan $\mathrm{L}_{\mathrm{obs}}$ $=0,1657$ pada pembelajaran 5 . Berdasarkan hasil uji normalitas bahwa data dinyatakan berdistribusi normal karena tidak berada atau lebih dari daerah kritik.

\section{(c) Hasil Uji Hipotesis}

Hipotesis penggunaan media flashcard tematik berbasis permainan tradisional adalah sebagai berikut:

$\mathrm{H}_{\mathrm{a}}$ : Terdapat perbedaan hasil belajar kognitif siswa setelah menggunakan media perbelajaran flashcard tematik berbasis permainan.

$\mathrm{H}_{\mathrm{o}}$ : Tidak terdapat perbedaan hasil belajar kognitif siswa setelah menggunakan media perbelajaran flashcard tematik berbasis permainan.

Berdasarkan hasil analisis data pada uji hipotesis pembelajaran 2 diperoleh $t_{\text {hitung }} 8,376$ dan $t_{\text {tabel }}$ 2,093. Kriteria pengujian keputusan uji $\mathrm{H}_{\mathrm{o}}$ diterima jika $t_{\text {hitung }} \leq t_{\text {tabel }}$ dan $\mathrm{H}_{\mathrm{a}}$ diterima jika $t_{\text {hitung }}>t_{\text {tabel }}$ sehingga dapat disimpulkan bahwa $\mathrm{H}_{\mathrm{a}}$ diterima dan $\mathrm{H}_{\mathrm{o}}$ ditolak karena $t_{\text {hitung }} 8,376=>t_{\text {tabel }}=$ 2,093.

Berdasarkan hasil analisis data pada uji hipotesis pembelajaran 5 diperoleh $t_{\text {hitung }} 7,264$ dan $t_{\text {tabel }}$ 2,093. Kriteria pengujian keputusan uji $\mathrm{H}_{\mathrm{o}}$ diterima jika $t_{\text {hitung }} \leq t_{\text {tabel }}$ dan $\mathrm{H}_{\mathrm{a}}$ diterima jika $t_{\text {hitung }}>t_{\text {tabel }}$. Hasil uji hipotesis pembelajaran 5 yaitu $\mathrm{H}_{\mathrm{a}}$ diterima dan $\mathrm{H}_{\mathrm{o}}$ ditolak karena $t_{\text {hitung }}=7,264>t_{\text {tabel }}=$ 2,093, sehingga dapat disimpulkan bahwa ada perbedaan antara sebelum dan sesudah digunakannya media pembelajaran flashcard berbasis permainan tradisional, atau dapat dikatakan bahwa media yang digunakan berpengaruh terhadap hasil belajar siswa.

Hasil belajar siswa dalam pembelajaran 2 menunjukkan bahwa semua siswa kelas IV SDN Gunungsari memperoleh nilai diatas KKM. Data awal menunjukkan ada 9 siswa memperoleh nilai di bawah KKM yang telah ditentukan sekolah yaitu sebesar 75 . Hasil belajar siswa dalam pembelajaran 5 juga menunjukkan adanya peningkatan. Data awal menunjukkan ada 15 siswa yang memperoleh nilai di atas KKM, setelah diberi perlakuan menunjukkan bahwa semua siswa kelas IV memperoleh nilai di atas KKM.

\section{d. Tahap Penyebaran}

Publikasi artikel ilmiah hasil implementasi di jurnal prodi PGSD Universitas PGRI Madiun. Tujuan publikasi yaitu menyebarluaskan hasil penelitian mengenai media pembelajaran yang dapat digunakan dalam pembelajaran tematik integratif di 
sekolah dasar, sehingga dapat memberikan manfaat untuk masyarakat luas.

\section{Pembahasan}

Media flashcard tematik merupakan media pengembangan dari flashcard. Penggunaan media flashcard tematik dipadukan dengan permainan tradisional keplakan dan tekpo yang awalnya dimainkan dengan menggunakan kartu umbul. Siswa dikelompokkan menjadi 4 kelompok selama pembelajaran dengan menggunakan media pembelajaran flashcard tematik berbasis permainan tradisional. Permainan diawali dengan membagikan flashcard challenge kepada masing-masing kelompok. Setiap kelompok memiliki flashcard yang sama dengan angka yang berbeda. Masingmasing perwakilan kelompok maju untuk memainkan permainan tradisional keplakan dan tekpo. Setiap anggota kelompok diharuskan bermain secara bergantian.

Permainan pertama yang dimainkan adalah tekpo. Cara bermain yaitu perwakilan kelompok secara bergantian menjadi bandar bertugas meletakkan flashcard challenge sesuai jumlah kelompok dan kelompok lain memilih flashcard tersebut. Bagi perwakilan kelompok yang memperoleh angka lebih rendah dari bandar wajib menjawab pertanyaan yang terdapat dalam flashcard challenge yang dipilih dengan berdiskusi dengan kelompoknya. Kelompok yang salah dalam menjawab pertanyaan harus menyerahkan satu flashcard challenge kepada bandar.

Permainan kedua yaitu keplakan. Setiap kelompok memilih satu perwakilan secara bergantian untuk bermain. Setiap perwakilan maju untuk menentukan lawan dengan cara "hom- pim-pah". Guru memberi aba-aba sebagai berikut "hom-pim-pah alaihum gambyeng”. Apabila ada dua siswa yang melakukan instruksi sama maka itu adalah lawan bermain. Secara bergantian pemain menepukkan flashcard challenge yang telah diletakkan di telapak tangan hingga jatuh ke bawah. Pemain yang flashcard challenge-nya menunjukkan sisi depan maka dia yang menjadi pemenang. Pemain yang kalah harus menjawab pertanyaan yang diberikan oleh pemain yang menang. Jika pemain tidak bisa menjawab pertanyaan maka flashcard-nya harus diberikan ke pemenang.

Pengembangan media dengan konsep bermain sambil belajar juga dapat menjadikan siswa lebih aktif, kreatif dan merasa senang karena akan membawa mereka ke dunia belajar yang awalnya membosankan menjadi menyenangkan. Berdasarkan hasil penelitian Syamsiana \& Lutfi (2014) yang dapat disimpulkan bahwa penyampaian materi pembelajaran yang dipadukan dengan permainan tradisional mempunyai daya tarik tersendiri bagi siswa, sehingga siswa lebih mudah menyerap materi dan mampu menciptakan pembelajaran yang menyenangkan bagi siswa.

Berdasarkan analisis data hasil pengujian produk media pembelajaran flashcard tematik berbasis permainan tradisional pembelajaran 2 dan 5 aspek materi dikategorikan bahwa media sangat layak sesuai dengan aspek-aspek penilaian kualitas isi dan instruksional. Penilaian kualitas isi menunjukkan bahwa media yang dikembangkan sesuai dengan materi yang terdapat dalam buku tema 8 Tempat Tinggalku, soal sesuai dengan indikator-indikator dalam pembelajaran dan isi atau penggunaan 
sesuai dengan tujuan pembelajaran serta aspek kebahasaan jelas dan mudah dipahami. Penilaian kualitas instruksional meliputi bahwa penggunaan flashcard tematik berbasis permainan tradisional harus dapat memberikan dampak bagi siswa maupun guru.

Berdasarkan pada hasil pengujian media pembelajaran flashcard berbasis permainan tradisional aspek media, hasil persentase nilai total dari empat komponen diperoleh hasil 93,33\% untuk komponen pertimbangan produksi diperoleh skor 9, komponen peserta didik, isi dan guru memperoleh skor maksimal 10. Hasil pengujian aspek media dikategorikan sangat layak dan dikatakan memadai untuk bisa dilakukan uji kelayakan dalam proses pembelajaran.

Hasil pengembangan media flashcard berbasis permainan tradisional dalam aspek materi dan media sesuai dengan hasil penelitian yang dilakukan Fatimah (2014) mengenai pengembangan media flash card dalam pembelajaran dengan judul "Pengembangan Media Flash Card dalam Pembelajaran Matematika untuk Siswa Kelas II MI Ma'arif Sendang Kulon Progo". Hasil pengembangan flash card menurut ahli materi dikategorikan baik dengan skor 4,00 dan menurut ahli media dikategorikan baik dengan skor 4,12.

Hasil analisis respon siswa baik dalam skala kecil dan luas juga menunjukkan bahwa media pembelajaran flashcard tematik berbasis permainan tradisional adalah sangat baik dengan persentase $100 \%$. Proses pembelajaran menggunakan flashcard tematik berbasis permainan tradisional sesuai dengan komponen ketertarikan, isi dan kemudahan yang dapat menimbulkan ketertarikan siswa, pengalaman siswa dan kemudahan dalam penggunaan maupun memahami materi. Hasil penelitian respon siswa setelah menggunakan media pembelajaran flashcard tematik berbasis permainan tradisional sesuai dengan penelitian yang dilakukan oleh Madasari dan \& Buditjahjanto (2012) dengan judul "Pengembangan Media Pembelajaran Flash Card Berbasis Komputer pada Standar Kompetensi Menjelaskan DasarDasar Sinyal Video di SMK Negeri 1 Sidoarjo. Hasil respon siswa memperoleh persentase $\quad 83,245 \quad \% \quad$ sehingga dikategorikan menarik.

Data yang diambil adalah data nilai posttest siswa setelah diberi perlakuan dengan menggunakan media pembelajaran flashcard tematik berbasis permainan tradisional. Data awal pretest sebelum diberi perlakuan berasal dari data guru berupa nilai kognitif pembelajaran 2 dan 5 .

Hasil belajar siswa dalam pembelajaran 2 dan 5 ditentukan dengan menggunakan uji t berpasangan. Syarat dilakukannya uji $\mathrm{t}$ berpasangan yaitu menggunakan uji normalitas. Berdasarkan hasil uji normalitas nilai dari 20 siswa setelah diberi perlakuan diperoleh $\mathrm{DK}=0,190$, dan $\mathrm{L}_{\mathrm{obs}}=0,1621$ pada pembelajaran 2 serta $\mathrm{DK}=0,190$ dan $\mathrm{L}_{\mathrm{obs}}=0,1657$ pada pembelajaran 5 . Berdasarkan hasil uji normalitas data dapat disimpulkan bahwa data dinyatakan berdistribusi normal karena tidak berada atau lebih dari daerah kritik.

Uji hipotesis digunakan untuk mengetahui hasil setalah diberi perlakukan. Uji hipotesis menggunakan uji t berpasangan setelah data dipastikan berasal dari populasi yang berdistribusi normal. Hipotesis dikelompokkan menjadi dua jenis, hipotesis nol $\left(\mathrm{H}_{0}\right)$ yang menyatakan tidak adanya perbedaan hasil 
belajar siswa setelah menggunakan media pembelajaran flashcard tematik berbasis permainan tradisional dan hipotesis alternatif $\left(\mathrm{H}_{\mathrm{a}}\right)$ yang menyatakan adanya perbedaan hasil belajar siswa setelah menggunakan media pembelajaran flashcard tematik berbasis permainan tradisional. Kriteria pengujian keputusan uji $\mathrm{H}_{0}$ diterima jika $t_{\text {hitung }} \leq \mathrm{t}_{\text {tabel }}$ dan $\mathrm{H}_{\mathrm{a}}$ diterima jika thitung $>t_{\text {tabel}}$.

Data awal sebelum diberi perlakuan menunjukkan ada 9 siswa dalam pembelajaran 2 memperoleh nilai di bawah KKM yang telah ditentukan sekolah yaitu sebesar 75 dengan nilai tertinggi 85 dan nilai terendah 55. Data awal dalam pembelajaran 5 juga menunjukkan ada 5 siswa yang memperoleh nilai di bawah KKM. Data hasil belajar aspek kognitif pembelajaran 5 ditunjukkan dengan nilai terendah 45 dan nilai tertinggi 85. Hasil belajar setelah diberi perlakuan menunjukkan bahwa semua siswa kelas IV memperoleh nilai di atas KKM.

Data hasil belajar sebelum dan setelah diberi perlakuan menunjukkan perbedaan yang signifikan antara dengan dan tanpa menggunakan media pembelajaran flashcard tematik berbasis permainan dalam pembelajaran tematik integratif pembelajaran 2 dan 5 sub tema Lingkungan Tempat Tinggalku. Perbedaan hasil belajar dibuktikan dengan hasil uji hipotesis yang telah dilakukan. Hasil analisis data pada uji hipotesis pembelajaran 2 diperoleh thitung $=8,376>\mathrm{t}_{\text {tabel }}=2,093$, sedangkan dalam pembelajaran 5 diperoleh hasil hipotesis yaitu $t_{\text {hitung }}=7,264>t_{\text {tabel }}=2,093$. Berdasarkan hasil dari uji hipotesis pembelajaran 2 dan 5 dapat disimpulkan bahwa ada perbedaan antara sebelum dan sesudah digunakannya media pembelajaran flashcard berbasis permainan tradisional, atau dapat dikatakan bahwa media yang digunakan berpengaruh terhadap hasil belajar siswa.

Penelitian serupa mengenai hasil belajar setelah menggunakan media flashcard juga telah diteliti oleh Maghfiroh (2013) dengan judul "Penggunaan Media Flash Card untuk Meningkatkan Hasil Belajar IPS Pada Pembelajaran Tematik di Sekolah Dasar". Hasil penelitian menunjukkan aktivitas siswa dalam pembelajaran mengalami peningkatan sebesar $12,5 \%$ dari $76,8 \%$ pada siklus I menjadi $89,3 \%$ pada siklus II. Ketuntasan klasikal hasil belajar siswa juga meningkat sebesar $24,3 \%$ yaitu dari $69,6 \%$ pada siklus I menjadi $93,9 \%$ pada siklus II. Berdasarkan data dan deskripsi yang telah dikemukakan dapat disimpulkan bahwa media pembelajaran flashcard tematik berbasis permainan tradisional efektif digunakan dalam proses pembelajaran karena setelah menggunakan media yang baru proses pembelajaran dan hasil belajar siswa meningkat.

\section{SIMPULAN}

Berdasarkan hasil analisis dan pembahasan pengembangan media pembelajaran flashcard tematik berbasis permainan tradisional, maka dapat disimpulkan sebagai berikut: (1) prosedur pengembangan media melalui empat tahap 4D yaitu define (pendefinisian), design (perancangan), develop (pengembangan) dan disseminate (penyebarluasan); (2) Hasil validasi dari dua validator dalam aspek materi dan media menunjukkan bahwa media flashcard tematik berbasis permainan tradisional untuk pembelajaran 2 dan 5 dikategorikan sangat layak digunakan 
dalam pembelajaran tematik integratif. Hasil pengujian aspek media menunjukkan persentase nilai total dari empat komponen diperoleh hasil 93,33\%, sedangkan pengujian produk media pembelajaran flashcard tematik berbasis permainan tradisional pembelajaran 2 dan 5 aspek materi dikategorikan bahwa media sangat layak sesuai dengan aspekaspek penilaian kualitas isi dan instruksional; (3) Hasil analisis respon siswa baik dalam skala kecil dan luas juga menunjukkan bahwa media pembelajaran flashcard tematik berbasis permainan tradisional adalah sangat baik dengan persentase $100 \%$. Proses pembelajaran menggunakan flashcard tematik berbasis permainan tradisional sesuai dengan komponen ketertarikan, isi dan kemudahan yang dapat menimbulkan ketertarikan siswa, pengalaman siswa dan kemudahan dalam penggunaan maupun memahami materi; (4) Hasil belajar siswa sebelum dan setelah diberi perlakuan menunjukkan perbedaan yang signifikan antara sebelum dan sesudah diberi perlakuan dalam pembelajaran 2 dan 5 sub tema Lingkungan Tempat Tinggalku. Hasil analisis data pada uji hipotesis pembelajaran 2 diperoleh $t_{\text {hitung }}=8,376>$ $\mathrm{t}_{\text {tabel }}=2,093$, sedangkan dalam pembelajaran 5 diperoleh hasil hipotesis yaitu $t_{\text {hitung }}=7,264>t_{\text {tabel }}=2,093$.

\section{DAFTAR RUJUKAN}

Anggraini, C. C. D. \& Untari, M. F. A. (2014). Keefektitas Model Permainan Boy-Boyan Terhadap Hasil Belajar Tema Driku Siswa Kelas 1 SD. Mimbar Sekolah Dasar, 1 (1), 92-98

Arifin, Z. (2011). Penelitian Pendidikan, Bandung: PT Remaja Rosdakarya.

Chirnawati, H.E., Usodo, B., Pramesthi, G., \& Sutopo. (2016).
Pengembangan Media Pembelajaran Desain Tematik: Upaya Meningkatkan Hasil Belajar Siswa dan Kemampuan Pengelolaan Kelas Bagi Guru SD dalam Implementasi Kurikulum 2013. JMEE, VI (2), 91-105.

Fatimah, S. (2014). Pengembangan Media Flash Card dalam Pembelajaran Matematika untuk Siswa Kelas II MI Ma'arif Sendang Kulon Progo. Skripsi tidak diterbitkan. Yogjakarta: Program Studi Pendidikan Guru Madrasah Ibtidaiyah Universitas Islam Negeri Sunan Kalijaga Yogyakarta.

Hidayat, D. (2013). Permainan Tradisional dan Kearifan Lokal Kampung Dukuh Garut Selatan Jawa Barat. Jurnal Academica Fisip Untad, 5 (2), 1057-1070

Indriani, F. (2015). Kompetensi Pedagogik Mahasiswa dalam Mengelola Pembelajaran Tematik Integratif Kurikulum 2013 pada Pembelajaan Micro di PGSD UAD Yogyakarta. Profesi Pendidikan Dasar, 2 (2), 87-97.

Madasari, C. A. \& Buditjahjanto, A. I. G. P. (2012). Pengembangan Media Pembelajaran Flash Card Berbasis Komputer pada Standar Kompetensi Menjelaskan Dasar-Dasar Sinyal Video di SMK Negeri 1 Sidoarjo. Jurnal Pendidikan Teknik Elektro, 1 (2).

Maghfiroh, L. (2013). Penggunaan Media Flash Card untuk Meningkatkan Hasil Belajar IPS Pada Pembelajaran Tematik di Sekolah Dasar. Jurnal Pendidikan Guru Sekolah Dasar, 1 (2), 1-13.

Musfiqon. (2012). Pengembangan Media dan Sumber Pembelajaran, Jakarta: Prestasi Pustakarya.

Syamsiana, F. \& Lutfi, A. (2014). Permainan Tradisional Selibur Sebagai Media Pembelajaran 
Struktur Atom pada Siswa SMA Negeri Ploso Jombang. Prosiding Seminar Nasional Kimia. Surabaya: Jurusan Kimia FMIPA Universitas Negeri Surabaya.

Yuliyanti, E. (2016). Pengembangan Pengelolaan Pembelajaran Tematik Berbasis Permainan Injak Kartu Angka pada Kelas 1 SD Negeri 2 Pulongrambe Kecamatan Tawangharjo Kabupaten Grobogan.Tesis tidak diterbitkan. Surakarta: Program Studi Magister Administrasi Pendidikan Universitas Muhammadiyah Surakarta. 